\title{
Apparent Gas-Phase Acidities of Multiply Protonated Peptide Ions: Ubiquitin, Insulin B, and Renin Substrate
}

\author{
Xin Zhang and Carolyn J. Cassady \\ Department of Chemistry, Miami University, Oxford, Ohio, USA
}

\begin{abstract}
The gas-phase deprotonation reactions of multiply protonated bovine ubiquitin, insulin chain $B$, and renin substrate tetradecapeptide ions have been studied in a Fourier transform ion cyclotron resonance mass spectrometer coupled with an external electrospray source. Rate constants were measured for the reactions of these peptide ions with a series of reference compounds of known gas-phase basicities ranging from 195.6 to $232.6 \mathrm{kcal} / \mathrm{mol}$. The apparent gas-phase acidities $\left(\mathrm{GA}_{\mathrm{app}}\right)$ of the multiply protonated peptide ions $[\mathrm{M}+n \mathrm{H}]^{n+}$ were determined with deprotonation reactions. The deduced values of $\mathrm{GA}_{\mathrm{app}}$ show a strong dependence on the charge states of the multiply protonated peptide ions. In general, the values decrease as the charge states of the peptide ions increase. For ubiquitin ions, the determined $\mathrm{GA}_{\mathrm{app}} \mathrm{s}$ values decrease from $>232.6$ to $205.0 \mathrm{kcal} / \mathrm{mol}$ for $n=4-13$; for insulin $\mathrm{B}$ ions, the $\mathrm{GA}_{\text {app }} \mathrm{s}$ decrease from $>232.6$ to $198.2 \mathrm{kcal} / \mathrm{mol}$ for $n=2-5$; for renin substrate ions, the $\mathrm{GA}_{\mathrm{app}} \mathrm{s}$ decrease from 221.6 to $<195.6 \mathrm{kcal} / \mathrm{mol}$ for $n=2-4$. Interestingly, at a given mass-to-charge ratio, the $\mathrm{GA}_{\mathrm{app}} \mathrm{s}$ of these peptide ions agree within 10 $\mathrm{kcal} / \mathrm{mol}$ despite large differences in their mass and charge. The ubiquitin and insulin $B$ ions generated under the present conditions reveal multiple isomers at certain charge states, $n=4,5,6,12$ for ubiquitin and $n=4,5$ for insulin $B$, as evidenced by the fact that the isomers display distinctively different deprotonation reaction rates with certain reference compounds. (C) 1996 American Society for Mass Spectrometry (J Am Soc Mass Spectrom 1996, 7, 1211-1218)
\end{abstract}

$\mathrm{T}$ The development of electrospray ionization (ESI) mass spectrometry has provided exceptional opportunities for studying large biomolecules in the gas phase [1-3]. In addition to offering new capabilities for analyzing biomolecules by mass spectrometry, ESI opens up a new class of ions for studies of gas-phase ion chemistry. A number of experimental techniques have been employed to probe gas-phase structures and ion chemistry such as proton transfer [4-13], hydrogen/deuterium exchange [13, 14], collision-induced dissociation $[13,15,16]$, collisional scattering $[17,18]$, and clustering reactions [19].

Proton transfer reactions in biological systems have been of long standing research interest. The highly protonated nature of biological ions generated by electrospray is ideal for experimental studies of proton transfer reactions in the gas phase. McLuckey et al. [4] were the first to demonstrate the dependence of reactivity on charge state for proton transfer reactions of large multiply charged ions. They found that the reaction rate increased as the charge state of multiply protonated ions of cytochrome $c$ increased when reacting with dimethylamine. In addition, deprotonation reactions of multiply protonated proteins were studied

Address reprint requests to Dr. Carolyn Cassady, Department of Chemistry, Miami University, Oxford, $\mathrm{OH} 45056$.

(C) 1996 American Society for Mass Spectrometry in a reaction chamber attached to the inlet of a triplequadrupole mass spectrometer by Ikonomou and Kebarle [5]; semiquantitative rates were determined for reactions of multiply charged cytochrome $c$ and tributylamine. Smith and co-workers [6-10] conducted a series of experiments to probe proton transfer reactions by using a "Y-tube" inlet/reactor coupled to a quadrupole mass spectrometer. Proton transfer reactions of both multiply charged cations with bases and multiply charged anions with acids were investigated. Recently, Cassady et al. [11, 13] measured the reaction rates of multiply charged ubiquitin ions with different bases in a Fourier transform ion cyclotron resonance (FT-ICR) mass spectrometer. Hunter et al. [12] studied the proton transfer reactions of multiply charged peptide ions with ammonia in a triple-quadrupole spectrometer. For highly protonated peptide ions, sequential deprotonation reaction products were observed.

Thermodynamic information, such as gas-phase acidity/basicity (GA/GB), is essential to the understanding of proton transfer processes in the gas phase. For a multiply protonated ion $[\mathrm{M}+n \mathrm{H}]^{n+}$, the gasphase acidity is related to the free energy change of reaction

$$
\begin{gathered}
{[\mathrm{M}+n \mathrm{H}]^{n+} \rightarrow[\mathrm{M}+(n-1) \mathrm{H}]^{(n-1)+}+\mathrm{H}^{+}} \\
\operatorname{GA}\left([\mathrm{M}+n \mathrm{H}]^{n+}\right)=\Delta \mathrm{G}
\end{gathered}
$$


while the gas-phase basicity of $[\mathrm{M}+(n-1) \mathrm{H}]^{(n-1)+}$ is related to the free energy change of the reverse reaction, that is,

$$
\begin{gathered}
{[\mathrm{M}+(n-1) \mathrm{H}]^{(n-1)+}+\mathrm{H}^{+} \rightarrow[\mathrm{M}+n \mathrm{H}]^{n+}} \\
\mathrm{GB}\left([\mathrm{M}+(n-1) \mathrm{H}]^{(n-1)+}=-\Delta G\right.
\end{gathered}
$$

Therefore, the quantity of GA([M $\left.+n \mathrm{H}]^{n+}\right)$ is the same as $\mathrm{GB}\left([\mathrm{M}+(n-1) \mathrm{H}]^{(n-1)+}\right)$. Since reaction 1 proceeds with a reverse activation barrier (RAB) due to the Coulomb repulsion of two charged product ions, the term "apparent gas-phase acidity" (GA app) was introduced by Bohme and co-workers $[20,21]$ and is defined as the sum of gas-phase acidity and the reverse activation barrier. It was suggested [20-22] that $\mathrm{GA}_{\mathrm{app}}$ is a more sensible term for a multiply charged ion $[\mathrm{M}+n \mathrm{H}]^{n+}$ because it is the quantity directly determined from deprotonation reactions and indicates the reactivity of $[\mathrm{M}+n \mathrm{H}]^{n+}$. In contrast, reaction 2 (which is the protonation of $[\mathrm{M}+(n-1) \mathrm{H}]^{(n-1)+}$ ) is barrier-inhibited, and gas-phase basicity is not directly measurable. However, $\mathrm{GB}_{\text {app }}$ also has been used in recent studies of multiply charged ions [23-28]. $\mathrm{GB}_{\text {app }}\left([\mathrm{M}+(n-1) \mathrm{H}]^{(n-1)+}\right)$ in those studies of deprotonation reactions [23-26] actually corresponds to $\mathrm{GA}_{\text {app }}\left([\mathrm{M}+n \mathrm{H}]^{n+}\right)$, while $\mathrm{GB}_{\mathrm{app}}\left([\mathrm{MH}]^{+}\right)$for dissociation of doubly protonated dimer $\left[{ }^{+} \mathrm{HM} \cdots \mathrm{H}^{+} \cdots \mathrm{B}\right]$ was defined as the sum of GB of $[\mathrm{MH}]^{+}$and the reverse activation barrier due to the Coulomb repulsion of $[\mathrm{MH}]^{+}$and $[\mathrm{BH}]^{+}[27,28]$. Therefore, $\mathrm{GA}_{\text {app }}$ will be used consistently for deprotonation processes throughout the following discussions.

Recently, several studies have been devoted to obtaining thermodynamic information of multiply charged biomolecules [24-28]. Gross and Williams [24] determined $\mathrm{GA}_{\text {app }} \mathrm{s}$ of doubly protonated gramicidin $\mathrm{S}$ and Williams and co-workers [25] determined $\mathrm{GA}_{\text {app }} \mathrm{s}$ of multiply protonated cytochrome $c$ ions. They also proposed a model to quantify Coulomb energy of ions at individual charge states [23-25]. In a further study [26], the model was applied to calculate the maximum charge state of peptide and protein ions formed by ESI. It was suggested that the maximum charge state observed by ESI is determined by the $\mathrm{GA}_{\text {app }} \mathrm{s}$ of multiply protonated peptide/protein ions and GBs of the solvent $[26]$. Fenselau and co-workers $[27,28]$ determined the GBs of protonated bradykinin and des-Arg ${ }^{9}$ bradykinin by measuring both $\mathrm{GB}_{\mathrm{app}} \mathrm{s}$ through the kinetic method and the reverse activation barriers by kinetic energy release.

In this work, gas-phase deprotonation reactions of multiply protonated bovine ubiquitin, insulin chain $B$, and renin substrate tetradecapeptide ions have been studied systematically in an FT-ICR. These peptides were chosen because they have ions with similar massto-charge ratios $(\mathrm{m} / z)$ but varying molar mass $(\mathrm{m})$. The apparent gas-phase acidities of the multiply protonated peptide ions $[\mathrm{M}+n \mathrm{H}]^{n+}$ were determined through deprotonation reactions. The implications of deduced GA $\mathrm{Gapp}_{\text {ap }}$ values are discussed in terms of acidities of deprotonation sites, Coulomb interaction, and structures of the peptides.

\section{Experimental}

All experiments were performed by using a Bruker (Billerica, MA) CMS-47X Fourier transform ion cyclotron resonance mass spectrometer coupled with an external ESI source. The experimental details have been described in previous publications [11, 13] and only those aspects pertinent to the present study are given here. Briefly, $(1.8-3.0) \times 10^{-5}-\mathrm{M}$ peptide solution formed in a 49.5:49.5:1.0 mixture (vol \%) of methanol:water:acetic acid was introduced into the source at a flow rate of $1.0-3.0 \mu \mathrm{L} / \mathrm{min}$. The liquid sample flowed through a grounded needle at atmospheric pressure and was electrosprayed across a 5-kV potential through a heated $\left(180^{\circ} \mathrm{C}\right) \mathrm{CO}_{2}$ countercurrent of drying gas. After passing through a series of ion optics, the ions were transferred to the ion cyclotron resonance (ICR) cell for reaction and subsequent detection. Multiple stages of differential pumping allowed a background pressure in the analyzer region of $3 \times 10^{-9}$ torr during the operation of the ESI source. To study deprotonation reactions, the multiply protonated peptide ion of interest was mass-to-charge ratio-selected by resonant-frequency-injection techniques [29] and allowed to react with static pressures of reference compounds. Pressures were measured with a calibrated ionization gauge [11]. The reaction rate constants were determined by observing the pseudofirst-order decay in reactant ion intensity as a function of reaction time. In cases where isomers exist and nonlinear kinetics were observed, the rate constants and corresponding percentage of each isomer were obtained by a best fit to the sum of multiple exponential decays. In the present study, isomers were able to be differentiated when their rate constants differ approximately by a factor of 10 and/or their levels of presence are about $10 \%$. Reported reaction efficiencies are the ratio of the experimental rate constant to the collisional rate constant obtained by using the average dipole orientation model [30].

The peptides, bovine ubiquitin, bovine insulin chain $B$, renin substrate tetradecapeptide (horse), and the reference compounds were purchased from Fluka (Ronkonkoma, NY), Sigma Chemical Co. (St. Louis, MO), and Aldrich Chemical Co. (St. Louis, MO) and were used without further purification.

\section{Results and Discussion}

\section{Deprotonation Reactions and Gas-Phase Acidities}

It has been well established [31-35] that the gas-phase acidity ( $\Delta G$ of deprotonation) of a protonated ion $\mathrm{AH}^{+}$ can be determined by studying the deprotonation reac- 
tions between $\mathrm{AH}^{+}$and a series of reference compounds $B$ with known gas-phase basicity:

$$
\mathrm{AH}^{+}+\mathrm{B} \rightarrow \mathrm{A}+\mathrm{BH}^{+}
$$

When $\mathrm{GA}$ of $\mathrm{AH}^{+}$is less than $\mathrm{GB}$ of $\mathrm{B}$ (note that $\mathrm{GB}$ of $B$ is also the $\mathrm{GA}$ of $\mathrm{BH}^{+}$), the deprotonation reaction proceeds at very low efficiency due to the endoergic reaction. When $\mathrm{GA}$ of $\mathrm{AH}^{+}$is greater than $\mathrm{GB}$ of $\mathrm{B}$, the deprotonation reaction is at high efficiency. The plot of reaction efficiencies as a function of $G B$ of the reference compounds generally displays an abrupt transition or break point. The corresponding value at the break point is assigned as $\mathrm{GA}$ of $\mathrm{AH}^{+}$. For example, Figure 1 displays reaction efficiencies [35] of the protonated peptide ion [GlySer] $\mathrm{H}^{+}$as a function of GBs of reference compounds. It is evident that a sharp transition of reaction efficiencies occurs in a narrow GB range. Hence, the determined GA values of the small monoprotonated peptides are not sensitive to the assignment of break point. A reaction efficiency criterion of 0.10 has been utilized in previous studies [34-36] as the break point, which generally represents a sharp transition between slow (endoergic) and facile (exoergic) deprotonation reactions.

In the case of multiply charged ions, $[\mathrm{M}+n \mathrm{H}]^{n+}$, the deprotonation reaction with reference compound, $B$, proceeds with a reverse activation barrier (RAB) due to the Coulombic repulsion of two charged product ions:

$$
[\mathrm{M}+n \mathrm{H}]^{n+}+\mathrm{B} \rightarrow[\mathrm{M}+(n-1) \mathrm{H}]^{(n-1)+}+\mathrm{BH}^{+}
$$

The value deduced from the deprotonation reaction is defined as the apparent gas-phase acidity of [M + $n \mathrm{H}]^{n+}[20,21]$; that is, the sum of the gas-phase acidity of $[\mathrm{M}+n \mathrm{H}]^{n}$ and the $\mathrm{RAB}$. For $[\mathrm{M}+n \mathrm{H}]^{n+}$, reaction efficiencies display a gradual increase as a function of the overall exoergicity of the deprotonation reactions, partially due to the large number of degrees of freedom to dissipate the excess energy in biomolecules. As

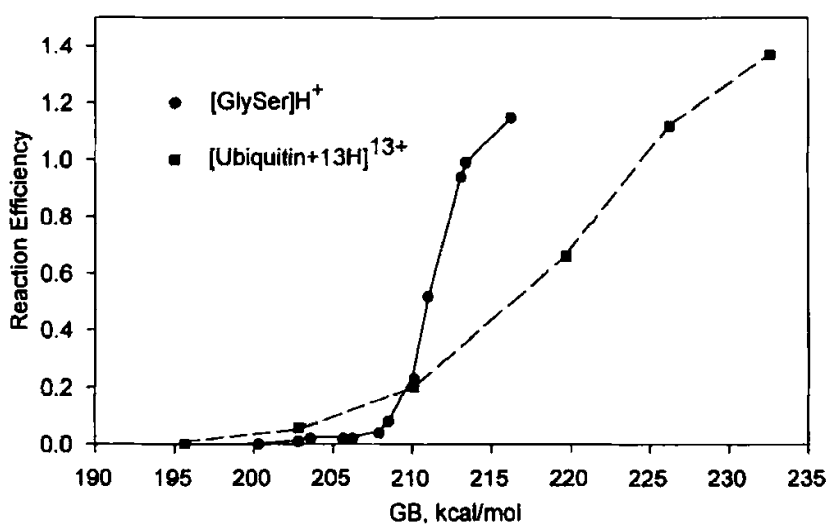

Figure 1. Plots of reaction efficiencies versus gas-phase basicity (GB) of reference compounds. an example, the reaction efficiencies of the multiply charged ubiquitin ion [ubiquitin $+13 \mathrm{H}$ ] $^{13+}$ are also plotted as a function of the GBs of reference compounds in Figure 1. It is evident that [ubiquitin + $13 \mathrm{H}]^{13+}$ shows a more gradual increase of reaction efficiencies as compared to [GlySer] $\mathrm{H}^{+}$. Therefore, the absolute value of apparent gas-phase acidity is quite sensitive to the assignment of the "break point." However, the relative values (or trend) at individual charge states are insensitive to the assignment of the break point, since the error associated with the assignment is systematic. In the present study, all the break points are assigned at reaction efficiencies equal to 0.1 since it also marks a transition in reaction efficiency plot as shown in Figure 1. Williams and co-workers [25] used a reaction efficiency around 0.00005 as the break point in their study of multiply protonated peptide ions. In a recent computational work [22], the $\mathrm{GA}_{\text {app }}$ of doubly protonated 1,7-diaminoheptane was determined as $\sim 200 \mathrm{kcal} / \mathrm{mol}$ from the calculated GA and the RAB. This value is substantially higher than the experimental value of $\sim 190 \mathrm{kcal} / \mathrm{mol}$ reported by Williams and co-workers [23]. By comparing the difference in the calculated and experimental $\mathrm{GA}_{\mathrm{app}}$ values, Gronert [22] suggested that a reaction efficiency value of $0.1-0.2$ may be more appropriate as a break point for determination of $\mathrm{GA}_{\mathrm{app}} \mathrm{s}$ of multiply protonated ions.

As has been previously noted [11], some reaction efficiencies are greater than 1 . This was attributed to the underestimation of collision rates calculated by average dipole orientation (ADO) [30] theory. Point charge is assumed in ADO theory but may not best describe large peptide ions. It is plausible that a large peptide ion has higher probability of undergoing a collision than a point charge. However, for large peptide ions, many collisions that might be energetically capable of leading to a reaction may not do so because of unfavorable geometric configuration, which may result in the maximum reaction rate less than the collision rate. This may offset the underestimation of the ADO collision rate to a certain extent. Also, to further complicate the situation, for reactions that are sufficiently exoergic, the peptide ion may have several sites where proton removal is energetically favorable; in contrast, for a near thermoneutral reaction, there may be only a single proton that the reference compound is capable of extracting. Although ADO theory is not ideal for large biomolecules, it is used here because there are no models available to calculate collision rates for large molecules. By using ADO rates we can, to some extent, take properties of the reference compounds and the effects of ion charge on rate constants into consideration.

\section{Reaction Efficiencies of Multiply Charged Peptide Ions}

In this work, the multiply protonated peptide ions $[\mathrm{M}+n \mathrm{H}]^{n+}$ were generated by electrospray ionization 
of solutions of denatured peptides. The highest charge states observed are $n=13,5$, and 4 for ubiquitin, insulin $B$, and renin substrate, respectively, which are equal to the total number of basic residues (arginine, lysine, and histidine) in the corresponding peptide plus one additional $N$-terminal protonation site. This observation is consistent with previous studies of peptides under similar conditions [11, 14].

A series of reference compounds with known gasphase basicities [37] was used for reactions with the selected peptide ions. In the ubiquitin system, the deprotonation reactions of multiply protonated ubiquitin ions, $[\mathrm{M}+n \mathrm{H}]^{n+}, n=4-13$, have been studied previously with four reference compounds [11]. In the present work, two additional reference compounds (ammonia and 2-fluoropyridine) are used to study the reactions of multiply protonated ubiquitin ions. For all the processes studied, deprotonation was the only sig- nificant reaction pathway. When highly protonated ions react with more basic compounds, sequential deprotonation reactions also occurred [11]. For most of the reactions studied, reactant ions exhibited linear first-order kinetics and reaction rate constants were determined by best fit of a single exponential decay. However, nonlinear kinetics [11, 13] were found for ubiquitin ions in the following cases: $[\mathrm{M}+4 \mathrm{H}]^{4+}$ with $N, N, N^{\prime}, N^{\prime}$-tetramethyl-1,4-butanediamine; [M + $5 \mathrm{H}]^{5+}$ with tripropylamine; $[\mathrm{M}+6 \mathrm{H}]^{6+}$ with dipropylamine; $[\mathrm{M}+12 \mathrm{H}]^{12+}$ with ammonia and 2fluoropyridine. All the experimental reaction rate constants $\left(k_{\exp }\right)$ and reaction efficiencies $\left(k_{\exp } / k_{\mathrm{ADO}}\right)$ are summarized in Table 1 . It can be seen that, in general, reaction rates increase as the charge states increase. This is in agreement with previous studies $[4,11,25]$.

Reactions of ions at charge states $n=2-5$ for insulin B and $n=2-4$ for renin substrate with six refer-

Table 1. Reaction rate constants and efficiencies of ubiquitin ions $\left[\mathrm{M}+n \mathrm{H}^{n+}\right.$

\begin{tabular}{|c|c|c|c|c|c|c|c|}
\hline$n$ & $\begin{array}{l}\text { Ref. compound } \\
\mathrm{GB}^{\mathrm{c}}(\mathrm{kcal} / \mathrm{mol})\end{array}$ & $\begin{array}{l}\mathrm{NH}_{3}{ }^{\mathrm{a}} \\
195.6\end{array}$ & $\begin{array}{l}2-\mathrm{FP}^{\mathrm{a}} \\
202.8\end{array}$ & $\begin{array}{l}N^{N P A^{b}} \\
210.1\end{array}$ & $\begin{array}{l}\text { DPA }^{\circ} \\
219.7\end{array}$ & $\begin{array}{l}\text { TPA }^{\mathrm{b}} \\
226.2\end{array}$ & $\begin{array}{l}T_{M D^{6}} \\
232.6\end{array}$ \\
\hline 13 & $\begin{array}{l}\operatorname{Exp}^{d} \\
\text { Effic }^{\theta}\end{array}$ & $\begin{array}{l}7.45 \times 10^{-12} \\
0.00036\end{array}$ & $\begin{array}{l}1.01 \times 10^{-9} \\
0.057\end{array}$ & $\begin{array}{l}2.70 \times 10^{-9} \\
0.20\end{array}$ & $\begin{array}{l}8.05 \times 10^{-9} \\
0.66\end{array}$ & $\begin{array}{l}1.29 \times 10^{-8} \\
1.12\end{array}$ & $\begin{array}{l}1.71 \times 10^{-8} \\
1.37\end{array}$ \\
\hline 12 & $\begin{array}{l}\text { Exp } \\
\text { Effic } \\
\text { Exp } \\
\text { Effic }\end{array}$ & $\begin{array}{l}5.40 \times 10^{-131} \\
0.00003(40 \%)^{9} \\
8.40 \times 10^{-12} \\
0.0004(60 \%)\end{array}$ & $\begin{array}{l}2.80 \times 10^{-121} \\
0.0002(54 \%) \\
3.80 \times 10^{-10} \\
0.0023(46 \%)\end{array}$ & $\begin{array}{l}1.56 \times 10^{-8} \\
0.12\end{array}$ & $\begin{array}{l}6.57 \times 10^{-9} \\
0.58\end{array}$ & $\begin{array}{l}8.81 \times 10^{-9} \\
0.83\end{array}$ & $\begin{array}{l}1.21 \times 10^{-8} \\
1.05\end{array}$ \\
\hline 11 & $\begin{array}{l}\text { Exp } \\
\text { Effic }\end{array}$ & $\begin{array}{l}1.01 \times 10^{-12} \\
0.00006\end{array}$ & $\begin{array}{l}2.67 \times 10^{-11} \\
0.0018\end{array}$ & $\begin{array}{l}4.44 \times 10^{-10} \\
0.039\end{array}$ & $\begin{array}{l}4.65 \times 10^{-9} \\
0.45\end{array}$ & $\begin{array}{l}7.54 \times 10^{-9} \\
0.77\end{array}$ & $\begin{array}{l}1.20 \times 10^{-8} \\
1.13\end{array}$ \\
\hline 10 & $\begin{array}{l}\text { Exp } \\
\text { Effic }\end{array}$ & $\begin{array}{l}3.26 \times 10^{-13} \\
0.00002\end{array}$ & $\begin{array}{l}1.59 \times 10^{-11} \\
0.0012\end{array}$ & $\begin{array}{l}2.39 \times 10^{-10} \\
0.023\end{array}$ & $\begin{array}{l}4.26 \times 10^{-9} \\
0.45\end{array}$ & $\begin{array}{l}3.82 \times 10^{-9} \\
0.43\end{array}$ & $\begin{array}{l}1.15 \times 10^{-8} \\
1.19\end{array}$ \\
\hline 9 & $\begin{array}{l}\text { Exp } \\
\text { Effic }\end{array}$ & $\begin{array}{l}3.76 \times 10^{-13} \\
0.00003\end{array}$ & $\begin{array}{l}1.58 \times 10^{-11} \\
0.0013\end{array}$ & $\begin{array}{l}1.60 \times 10^{-10} \\
0.017\end{array}$ & $\begin{array}{l}4.38 \times 10^{-9} \\
0.52\end{array}$ & $\begin{array}{l}4.42 \times 10^{-9} \\
0.55\end{array}$ & $\begin{array}{l}9.18 \times 10^{-9} \\
1.06\end{array}$ \\
\hline 8 & $\begin{array}{l}\text { Exp } \\
\text { Effic }\end{array}$ & $\begin{array}{l}2.25 \times 10^{-13} \\
0.00002\end{array}$ & $\begin{array}{l}8.77 \times 10^{-12} \\
0.0007\end{array}$ & $\begin{array}{l}2.78 \times 10^{-11} \\
0.0033\end{array}$ & $\begin{array}{l}4.05 \times 10^{-9} \\
0.54\end{array}$ & $\begin{array}{l}4.39 \times 10^{-9} \\
0.62\end{array}$ & $\begin{array}{l}9.44 \times 10^{-9} \\
1.23\end{array}$ \\
\hline 7 & $\begin{array}{l}\text { Exp } \\
\text { Effic }\end{array}$ & $N A^{h}$ & $\begin{array}{l}3.64 \times 10^{-13} \\
0.00004\end{array}$ & NA & $\begin{array}{l}7.68 \times 10^{-10} \\
0.12\end{array}$ & $\begin{array}{l}2.37 \times 10^{-9} \\
0.38\end{array}$ & $\begin{array}{l}8.96 \times 10^{-9} \\
1.33\end{array}$ \\
\hline 6 & $\begin{array}{l}\text { Exp } \\
\text { Effic } \\
\text { Exp } \\
\text { Effic }\end{array}$ & NA & NA & NA & $\begin{array}{l}2.76 \times 10^{-10} \\
0.049(80 \%) \\
1.13 \times 10^{-11} \\
0.0020(20 \%)\end{array}$ & $\begin{array}{l}6.17 \times 10^{-10} \\
0.12\end{array}$ & $\begin{array}{l}5.99 \times 10^{-9} \\
1.04\end{array}$ \\
\hline 5 & $\begin{array}{l}\text { Exp } \\
\text { Effic } \\
\text { Exp } \\
\text { Effic }\end{array}$ & NA & NA & NA & NA & $\begin{array}{l}7.05 \times 10^{-10} \\
0.15(59 \%) \\
1.93 \times 10^{-11} \\
0.0042(41 \%)\end{array}$ & $\begin{array}{l}3.76 \times 10^{-9} \\
0.78\end{array}$ \\
\hline 4 & $\begin{array}{l}\text { Exp } \\
\text { Effic } \\
\text { Exp } \\
\text { Effic } \\
\text { Exp } \\
\text { Effic }\end{array}$ & NA & NA & NA & NA & NA & $\begin{array}{l}4.41 \times 10^{-10} \\
0.12(62 \%) \\
2.78 \times 10^{-11} \\
0.007(30 \%) \\
<1.00 \times 10^{-12} \\
0.0002(8 \%)\end{array}$ \\
\hline
\end{tabular}

Data from present work. 2-FP $=2$-fluoropyridine.

'Data from ref $11 ; \mathrm{NPA}=n$-propylamine; $\mathrm{DPA}=$ di-n-propylamine; TPA $=$ tri-n-propylamine; TMD $=N, N, N^{\prime}, N^{\prime}$-tetramethyl-1,4-butanediamine.

All GBs of reference compounds are from ref 37.

Experimental rate constants are in units of centimeter cubed per molecule per second.

Reaction efficiencies are the ratio of the experimental and theoretical rate constants: $k_{\mathrm{Bxp}} / k_{\mathrm{ADO}}$.

'Data from ref 13.

In cases where an ion reacts at multiple rates, the percentage of the population reacting with each rate constant is shown in parentheses.

${ }^{\mathrm{h}} \mathrm{NA}$ indicates that an ion did not form in sufficient intensity for study with the reference compound of interest. 
ence compounds were also studied in the present work. In cases where the ion of interest was not formed in high yield by ESI (e.g., $n=4-7$ for ubiquitin, $n=2,3$ for insulin $\mathrm{B}$, and $n=2$ for renin substrate), the entire ion population was allowed to react with the reference compound to shift the distribution to lower charge state prior to ion isolation [11]. All these deprotonation reactions exhibit linear first-order kinetics except reactions of [insulin $+4 \mathrm{H}]^{4+}$ and [insulin $\left.+5 \mathrm{H}\right]^{5+}$ with 2-fluoropyridine, where nonlinear kinetics were observed. Similar to the ubiquitin ions, deprotonation reactions were the only significant reaction pathway in all cases with two exceptions: doubly protonated renin substrate with $n$-propylamine and dipropylamine, where only adduct ions were formed. The results of these two systems are summarized in Table 2.

\section{Determination of $G A_{a p p} s$}

By using a reaction efficiency of 0.1 as the break point between endoergic and exoergic processes, the apparent gas-phase acidities of multiply charged peptide ions were determined and summarized in Table 3 . In cases where the reaction efficiencies are substantially below or above the break point, only a low or a high limit of $\mathrm{GA}_{\text {app }}$ is given. The error of the determined $\mathrm{GA}_{\mathrm{app}} \mathrm{S}$ is estimated as half of the GB difference of two nearest reference compounds at the break point plus an additional 2-kcal/mol error for literature values. Although the error of the determined $\mathrm{GA}_{\text {app }} s$ is fairly large due to the large GB gap between reference base compounds, the relative values among different charge states are readily established.

To better visualize the general trend, the determined $\mathrm{GA}_{\mathrm{app}} \mathrm{s}$ are plotted as a function of charge state in Figure 2. Also included in Figure 2 are the experimental $\mathrm{GA}_{\mathrm{app}} \mathrm{s}$ of multiply protonated cytochrome $c$ ions $[\mathrm{M}+n \mathrm{H}]^{n+}, n=4-16$, determined by Williams and co-workers [25]. From Figure 2, it is obvious that the $\mathrm{GA}_{\text {app }}$ values decrease as the charge states of the peptide ions increase. This can be attributed to several factors: intrinsic GA of the deprotonation site, Coulomb energy, and three-dimensional structures. It is known that protonated arginine is the most acidic amino acid with a GA of $235.8 \mathrm{kcal} / \mathrm{mol}$ [38], while protonated lysine and histidine have similar acidity with GAs of $220.8 \mathrm{kcal} / \mathrm{mol}$ [39], which is substantially lower than that of arginine. It is reasonable to assume that arginine is a more preferred site for protonation at low charge states and therefore deprotonation reactions are more likely to proceed at protonated arginine sites. At higher charge states, the deprotonation reactions may occur at less acidic sites. This is consistent with the decreasing trend of $\mathrm{GA}_{\text {app }} \mathrm{s}$. Furthermore, as the charge state increases, the Coulomb energy increases significantly [25]. This would also lead to reduced gas-

Table 2. Reaction rate constants and efficiencies of insulin $\mathrm{B}$ and renin substrate ions $[\mathrm{M}+n \mathrm{H}]^{n+a}$

\begin{tabular}{|c|c|c|c|c|c|c|c|}
\hline$n$ & $\begin{array}{l}\text { Ref. compound } \\
\mathrm{GB}^{b}(\mathrm{kcal} / \mathrm{mol})\end{array}$ & $\begin{array}{l}\mathrm{NH}_{3} \\
195.6\end{array}$ & $\begin{array}{l}2 \cdot F P \\
202.8\end{array}$ & $\begin{array}{l}\text { NPA } \\
210.1\end{array}$ & $\begin{array}{l}\text { DPA } \\
219.7\end{array}$ & $\begin{array}{l}\text { TPA } \\
226.2\end{array}$ & $\begin{array}{l}\text { TMD } \\
232.6\end{array}$ \\
\hline \multicolumn{8}{|c|}{ Insulin, chain B } \\
\hline 5 & $\begin{array}{l}\operatorname{Exp}^{c} \\
\text { Effic }^{d} \\
\text { Exp } \\
\text { Effic }\end{array}$ & $\begin{array}{l}2.82 \times 10^{-11} \\
0.0036\end{array}$ & $\begin{array}{l}1.09 \times 10^{-10} \\
0.016(38 \%)^{\theta} \\
1.86 \times 10^{-9} \\
0.27(62 \%)\end{array}$ & $\begin{array}{l}5.47 \times 10^{-9} \\
1.04\end{array}$ & $\begin{array}{l}4.73 \times 10^{-9} \\
0.99\end{array}$ & $\begin{array}{l}6.61 \times 10^{-9} \\
1.48\end{array}$ & $\begin{array}{l}5.85 \times 10^{-9} \\
1.20\end{array}$ \\
\hline 4 & $\begin{array}{l}\text { Exp } \\
\text { Effic } \\
\text { Exp } \\
\text { Effic }\end{array}$ & $\begin{array}{l}6.59 \times 10^{-12} \\
0.0010\end{array}$ & $\begin{array}{l}2.10 \times 10^{-11} \\
0.0038(32 \%) \\
3.50 \times 10^{-10} \\
0.064(68 \%)\end{array}$ & $\begin{array}{l}2.27 \times 10^{-9} \\
0.54\end{array}$ & $\begin{array}{l}4.06 \times 10^{-9} \\
1.07\end{array}$ & $\begin{array}{l}3.54 \times 10^{-9} \\
0.99\end{array}$ & $\begin{array}{l}3.74 \times 10^{-9} \\
0.96\end{array}$ \\
\hline 3 & $\begin{array}{l}\text { Exp } \\
\text { Effic }\end{array}$ & $\mathrm{NA}^{\prime}$ & NA & NA & $\begin{array}{l}1.10 \times 10^{-9} \\
0.38\end{array}$ & $\begin{array}{l}1.79 \times 10^{-9} \\
0.67\end{array}$ & $\begin{array}{l}1.77 \times 10^{-9} \\
0.61\end{array}$ \\
\hline 2 & $\begin{array}{l}\text { Exp } \\
\text { Effic }\end{array}$ & NA & NA & NA & NA & NA & $\mathrm{NR}^{9}$ \\
\hline \multicolumn{8}{|c|}{ Renin substrate tetradecapeptide } \\
\hline 4 & $\begin{array}{l}\text { Exp } \\
\text { Effic }\end{array}$ & $\begin{array}{l}1.08 \times 10^{-9} \\
0.17\end{array}$ & $\begin{array}{l}2.75 \times 10^{-9} \\
0.49\end{array}$ & $\begin{array}{l}2.36 \times 10^{-9} \\
0.55\end{array}$ & $\begin{array}{l}4.56 \times 10^{-9} \\
1.18\end{array}$ & $\begin{array}{l}2.75 \times 10^{-9} \\
0.76\end{array}$ & $\begin{array}{l}3.16 \times 10^{-9} \\
0.76\end{array}$ \\
\hline 3 & $\begin{array}{l}\text { Exp } \\
\text { Effic }\end{array}$ & NR & $\begin{array}{l}9.96 \times 10^{-12} \\
0.002\end{array}$ & $\begin{array}{l}9.17 \times 10^{-10} \\
0.29\end{array}$ & $\begin{array}{l}2.75 \times 10^{-9} \\
0.95\end{array}$ & $\begin{array}{l}2.20 \times 10^{-9} \\
0.81\end{array}$ & $\begin{array}{l}2.30 \times 10^{-9} \\
0.74\end{array}$ \\
\hline 2 & $\begin{array}{l}\text { Exp } \\
\text { Effic }\end{array}$ & NA & NA & $\begin{array}{l}1.70 \times 10^{-11} \\
0.008\end{array}$ & $\begin{array}{l}2.80 \times 10^{-10} \\
0.15\end{array}$ & $\begin{array}{l}6.19 \times 10^{-10} \\
0.34\end{array}$ & $\begin{array}{l}8.81 \times 10^{-9} \\
0.44\end{array}$ \\
\hline
\end{tabular}

2-FP $=2$-fluoropyridine; NPA $=n-p$ ropylamine; DPA $=$ di-n-propylamine; TPA $=$ tri-n-propylamine: TMD $=N, N, N^{\prime}, N^{\prime} \cdot$ tetramethyl-1,4-butanediamine.

${ }^{6}$ All GBs of reference compounds are from ref 37.

Experimental rate constants are in units of centimeters cubed per molecule per second.

Reaction efficiencies are the ratio of the experimental and theoretical rate constants: $k_{\text {exp }} / k_{A D O}$

In cases where an ion reacts at multiple rates, the percentage of the population reacting with each rate constant is shown in parentheses.

NA indicates that an ion did not form in sufficient intensity for study with the reference compound of interest.

${ }^{9} \mathrm{NR}$ indicates that no reaction was observed. 
phase acidity. It is important to realize that the threedimensional structures as well as the solvation energy of a peptide at various charge states may be different. The ions at small charge states may have a more compact structure with higher solvation energy. This is supported by the findings that neutral peptides have substantially higher gas-phase basicities than the intrinsic gas-phase basicities of amino acids [25, 28]. The structures may become less compact at higher charge states due to the increasing Coulomb repulsion. Therefore, the acidity of the peptide ions would decrease as charge state increases.

It is interesting to note the deduced $\mathrm{GA}_{\mathrm{app}} \mathrm{s}$ of both renin substrate and insulin B drop significantly $(>25$ $\mathrm{kcal} / \mathrm{mol}$ ) from $n=2-4$, while the values of ubiquitin show a more gradual change as a function of charge state from $n=4-13$ as shown in Figure 2. Since the molecular weights (renin substrate of $1759.1 \mathrm{u}$; insulin $B$ of $3495.9 \mathrm{u}$; ubiquitin of $8564.8 \mathrm{u}$ ) and the charge states are quite different for these peptides, the $\mathrm{GA}_{\mathrm{app}} \mathrm{s}$ are plotted as a function of mass-to-charge ratio in Figure 3 to further understand the general $\mathrm{GA}_{\mathrm{app}} \mathrm{s}$ trend. Also included in Figure 3 are the experimental $\mathrm{GA}_{\text {app }}$ s of multiply protonated cytochrome $c$ [25]. Interestingly, the $G A_{\text {app }}$ s generally agree within about $10 \mathrm{kcal} / \mathrm{mol}$ at a given mass-to-charge ratio value

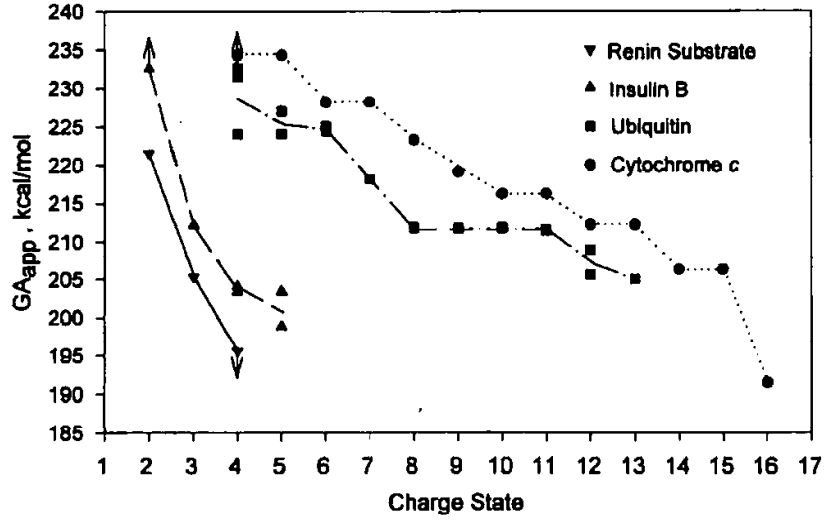

Figure 2. Plots of apparent gas-phase acidities $\left(\mathrm{GA}_{\text {app }}\right)$ of multiply protonated peptide ions, $[\mathrm{M}+n \mathrm{H}]^{n+}$, as a function of their charge state $n$. (Cytochrome $c$ data from ref 25)

(with only a few exceptions) despite large differences in molecular weight and charge state of these peptides. This correlation of $\mathrm{GA}_{\text {app }}$ with mass-to-charge ratio may be due to the fact that $1 /(\mathrm{m} / \mathrm{z})$ provides a qualitative measure of average charge separation. The smallest peptide studied-renin substrate-deviates most from this observation; this may suggest that as the number of potential protonation sites decreases,

Table 3. Apparent gas-phase acidities $\left(\mathrm{GA}_{\text {app }}\right)$ for deprotonation of peptide ions $[\mathrm{M}+n \mathrm{H}]^{n+}$

\begin{tabular}{|c|c|c|c|}
\hline Peptide & $n$ & $m / z$ & $\mathrm{GA}_{\mathrm{app}}(\mathrm{kcal} / \mathrm{mol})$ \\
\hline \multirow[t]{10}{*}{ Ubiquitin (bovine) } & 13 & 660 & $205.0 \pm 5.7$ \\
\hline & 12 & 715 & $\begin{array}{l}205.6 \pm 5.7(50 \%)^{\circ} \\
208.9 \pm 5.7(50 \%)\end{array}$ \\
\hline & 11 & 780 & $211.5 \pm 6.8$ \\
\hline & 10 & 857 & $211.8 \pm 6.8$ \\
\hline & 9 & 952 & $211.7 \pm 6.8$ \\
\hline & 8 & 1072 & $211.8 \pm 6.8$ \\
\hline & 7 & 1225 & $218.1 \pm 5.3$ \\
\hline & 6 & 1428 & $\begin{array}{l}224.4 \pm 5.3(80 \%) \\
225.1 \pm 5.3(20 \%)\end{array}$ \\
\hline & 5 & 1714 & $\begin{array}{l}224.0 \pm 5.3(59 \%) \\
227.0 \pm 5.3(41 \%)\end{array}$ \\
\hline & 4 & 2143 & $\begin{aligned} & 224.0 \pm 5.3(62 \%) \\
& 231.5 \pm 5.3(30 \%) \\
> & 232.6(8 \%)\end{aligned}$ \\
\hline \multirow[t]{4}{*}{ Insulin, chain B } & 5 & 700 & $\begin{array}{l}198.2 \pm 5.6(38 \%) \\
203.4 \pm 5.7(62 \%)\end{array}$ \\
\hline & 4 & 875 & $\begin{array}{l}203.4 \pm 5.7(68 \%) \\
204.1 \pm 5.7(32 \%)\end{array}$ \\
\hline & 3 & 1166 & $212.2 \pm 6.8$ \\
\hline & 2 & 1749 & $>232.6$ \\
\hline \multirow[t]{2}{*}{$\begin{array}{l}\text { Renin substrate } \\
\text { tetradecapeptide }\end{array}$} & 4 & 441 & $<195.6$ \\
\hline & $\begin{array}{l}3 \\
2\end{array}$ & $\begin{array}{l}587 \\
880\end{array}$ & $\begin{array}{l}205.3 \pm 5.7 \\
221.6 \pm 5.3\end{array}$ \\
\hline
\end{tabular}

\footnotetext{
${ }^{a}$ In cases where multiple isomers exist, the percentage of the ion population that has the listed GA
} is shown in parentheses. 


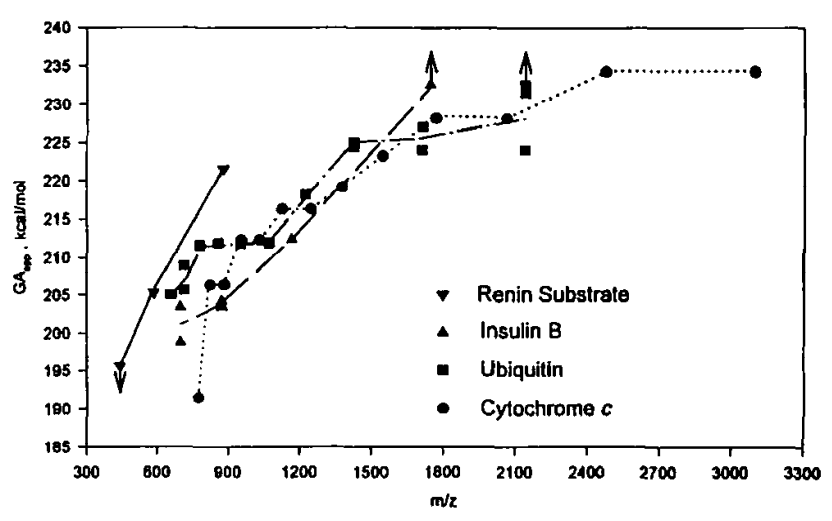

Figure 3. Plots of apparent gas-phase acidities $\left(\mathrm{GA}_{\text {app }}\right)$ of multiply protonated peptide ions, $[\mathrm{M}+n \mathrm{H}]^{n+}$, as a function of their mass-to-charge ratio $m / z$. (Cytochrome $c$ data from ref 25)

the intrinsic basicity of the protonation sites becomes more of a factor. Further studies are needed to generalize and understand these empirical observations.

\section{General Considerations of GA Determination from $G A_{a p p}$}

To determine GA of multiply charged ions from experimentally measured $\mathrm{GA}_{\text {app}}$, the reverse activation barrier has to be known. In several studies of dications $[22,27,28]$, the RABs were determined either theoretically by ab initio calculations [22] or experimentally through kinetic energy release measurements [27, 28]. Values obtained from these studies are readily different for different systems; for example, a RAB of 18 $\mathrm{kcal} / \mathrm{mol}$ was determined for deprotonation of doubly protonated 1,7-diaminoheptane [22], while RABs of 13.6 and $22.4 \mathrm{kcal} / \mathrm{mol}$ were obtained for dissociation of doubly protonated bradykinin-(leucine-enkephalin) and (des-Arg ${ }^{9}$-bradykinin)-tripeptide, respectively [27, 28]. It was suggested $[22,27,28]$ that locations of protonation sites and structures of the ions have great impact on the reverse activation barrier. For multiply protonated ions, Williams and co-workers [23-26] estimated RABs by calculating the Coulomb repulsions in the reactant complexes. However, Gronert's [22] calculations indicated that even for a dication, the RAB $(\sim 18 \mathrm{kcal} / \mathrm{mol})$ is much smaller than the Coulomb repulsion $(\sim 30 \mathrm{kcal} / \mathrm{mol})[23]$ in the reactant. The overestimation of RABs by the Coulomb repulsions of highly protonated ions may be more severe since the Coulomb repulsion may increase much more rapidly than the reverse activation barrier as charge state increases. Therefore, to determine GA of multiply charged ions from $\mathrm{GA}_{\text {app }}$ a reliable theoretical model or experimental method (for example, kinetic energy release measurements) is needed to obtain the reverse activation barrier. It should be emphasized that although GA represents the fundamental acidity of a multiply charged ion, $\mathrm{GA}_{\text {app }}$ is also important since it is directly related to the "observable acidity" of a multiply charged ion. Thus, $\mathrm{GA}_{\text {app }}$ is the value that a mass spectrometrist needs to know to experimentally shift the charge state of a multiply protonated ion.

\section{Implication of $G A_{a p p} s$ to Isomeric Structures}

In previous studies [11, 13], nonlinear kinetics were observed for reactions of ubiquitin ions at several charge states, $n=4,5,6,12$. In the present work, nonlinear kinetics were also seen in reactions of [insulin $+4 \mathrm{H}]^{4+}$ and [insulin $\left.+5 \mathrm{H}\right]^{5+}$ with 2-fluoropyridine. Nonlinear kinetic behavior is generally indicative of the existence of multiple isomers. It can be seen from Table 3 that these isomers do have distinctively different $\mathrm{GA}_{\mathrm{app}} \mathrm{s}$, which may result from the differences of protonation sites and/or threedimensional structures.

It is interesting to note that isomers are only distinguishable when reacting with selected reference compounds. For example, [insulin $+4 \mathrm{H}]^{4+}$ revealed two isomers only when reacting with 2-fluoropyridine. This is probably due to the fact that the GB of 2-fluoropyridine $(202.8 \mathrm{kcal} / \mathrm{mol})$ [37] is very close to the $\mathrm{GA}_{\text {app }} \mathrm{s}$ of the two isomers $(203.4$ and $204.1 \mathrm{kcal} / \mathrm{mol}$ ) making these reactions near thermoneutral. As another example, [insulin $+5 \mathrm{H}]^{5+}$ revealed two isomers only when reacting with 2-fluoropyridine since the GB of 2-fluoropyridine (202.8 kcal/mol) [37] is between the $\mathrm{GA}_{\text {app }}$ of the fast-reacting isomer $(198.2 \mathrm{kcal} / \mathrm{mol})$ and the $\mathrm{GA}_{\mathrm{app}}$ of the slow-reacting isomer $(203.4 \mathrm{kcal} / \mathrm{mol})$. In general, when the $\mathrm{GB}$ of the reference compound is substantially higher or lower than $\mathrm{GA}_{\mathrm{app}} \mathrm{s}$ of both isomers, the reaction becomes either too fast or too slow to differentiate these isomers. Therefore, selection of appropriate reference compounds is critical for differentiating different isomers through deprotonation reactions.

\section{Conclusion}

The apparent gas-phase acidities of multiply protonated ubiquitin, insulin $B$, and renin substrate ions were determined through deprotonation reactions. The deduced $\mathrm{GA}_{\text {app }}$ values decrease as the charge states of the peptide ions increase. At a given mass-to-charge ratio $(m / z)$, the obtained $\mathrm{GA}_{\text {app }} \mathrm{s}$ of ions with different mass $(m)$ and charge state $(z)$ generally agree within about $10 \mathrm{kcal} / \mathrm{mol}$. Furthermore, multiply protonated insulin B and ubiquitin ions at certain charge states reveal isomeric structures, as evidenced by the fact that these isomers have different $\mathrm{GA}_{\mathrm{app}} \mathrm{s}$.

\section{Acknowledgments}

The authors thank S. R. Carr for his contribution in data collection. The authors are indebted to Bruker Instruments for the loan of the ESI source and to G. H. Kruppa, J. Wronka, C. C. Stacey, and F. H. Laukien for assistance in utilizing the source. Financial support by the National Institutes of Health (R01-GM51384-01A1) and the Ohio Board of Regents Action Fund and Academic Challenge Program is gratefully acknowledged. 


\section{References}

1. Fenn, J. B.; Mann, M.; Meng, C. K.; Wong, S. F.; Whitehouse, C. M. Science. 1989, 246, 64-71.

2. Fenn, J. B.; Mann, M.; Meng, C. K.; Wong, S. F.; Whitehouse C. M. Mass Spectrom. Rev. 1990, 9, 37-70.

3. Smith, R. D.; Loo, J. A.; Edmonds, C. G.; Barinaga, C. J.; Udseth, H. R. Anal. Chem. 1990, 62, 882-899.

4. McLuckey, S. A.; Van Berkel, G. J.; Glish, G. L. J. Am. Chem. Soc. 1990, 112, 5668-5670.

5. Ikonomou, M. G.; Kebarle, P. Int. J. Mass Spectrom. Ion Processes 1992, 117, 283-298.

6. Ogorzalek Loo, R. R.; Loo, J. A.; Udseth, H. R.; Fulton, J. L.; Smith, R. D. Rapid Commun. Mass Spectrom. 1992, 6, 159-165.

7. Winger, B. E.; Light-Wahl, K. J.; Ogorzalek Loo, R. R.; Udseth, H. R.; Smith, R. D. I. Am. Soc. Mass Spectrom. 1993, 4, 536-545.

8. Ogorzalek Loo, R. R.; Smith, R. D. J. Am. Soc. Mass Spectrom. 1994, 5, 207-220.

9. Ogorzalek Loo, R. R.; Winger, B. E.; Smith, R. D. I. Am. Soc. Mass Spectrom. 1994, 5, 1064-1071.

10. Ogorzalek Loo, R. R.; Smith, R. D. I. Mass Spectrom. 1995, 30 339-347.

11. Cassady, C. J.; Wronka, J.; Kruppa, G. H.; Laukien, F. H. Rapid Commun. Mass Spectrom. 1994, 8, 394-400.

12. Hunter, A. P.; Severs, J. C.; Harris, F. M.; Games, D. E. Rapid Commun. Mass Spectrom. 1994, 8, 417-422.

13. Cassady, C. J.; Carr, S. R. J. Mass Spectrom. 1996, 31, 247-254.

14. Suckau, D.; Shi, Y.; Beu, S. C.; Senko, M. W.; Quinn, J. P.; Wampler, F. M., III; McLafferty, F. W. Proc. Natl. Acad. Sci. USA 1993, 90, 790-793.

15. Loo, J. A.; Edmonds, C. G.; Smith, R. D. Anal. Chem. 1993, 65, 425-438.

16. Feng, R.; Konishi, Y. Anal. Chem. 1993, 65, 645-649.

17. Covey, T. R.; Douglas, D. J. J. Am. Soc. Mass Spectrom. 1993, $4,616-623$.

18. Cox, K. A.; Julian, R. K.; Cooks, R. G.; Kaiser, R. E. J. Am. Soc. Mass Spectrom. 1994, 5, 127-136.

19. Morris, M.; Thibault, P.; Boyd, R. K. Rapid Commun. Mass Spectrom. 1993, 7, 1136-1140.
20. Petrie, S.; Javahery, G.; Bohme, D. K. Int. J. Mass Spectrom. Ion Processes 1993, 124, 145-156.

21. Petrie, S.; Javahery, G.; Wincel, H.; Bohme, D. K. J. Am. Chem. Soc. 1993, 115, 6290-6294.

22. Gronert, S. J. Am. Chem. Soc. 1996, 118, 3525-3526.

23. Gross, D. S.; Rodriguez-Cruz, S. E.; Williams, E. R. I. Phys. Chem. 1995, 99, 4034-4038.

24. Gross, D. S.; Williams, E. R. I. Am. Chem. Soc. 1995, 117, 883-890.

25. Schnier, P. D.; Gross, D. S.; Williams, E. R. J. Am. Chem. Soc. 1995, 117, 6747-6757.

26. Schnier, P. D.; Gross, D. S.; Williams, E. R. I. Am. Soc. Mass Spectrom. 1995, 6, 1086-1097.

27. Kaltashov, 1. A.; Fabris, D.; Fenselau, C. C. J. Phys. Chem. 1995, 99, 10046-10051.

28. Kaltashov, I. A.; Fenselau, C. C. J. Am. Chem. Soc. 1995, 117, 9906-9910.

29. Comisarow, M. B.; Grassi, V.; Parisod, G. Chem. Phys. Lett. 1978, 57, 413-416.

30. Su, T.; Bowers, M. T. Int. I. Mass Spectrom. Ion Phys. 1973, 12, 347-356.

31. DeFrees, D. J.; McIver, R. T., Jr.; Hehre, W. J. J. Am. Chem. Soc. 1980, 102, 3334-3338.

32. Gorman, G. S.; Spier, J. P.; Turner, C. A.; Amster, I. J. J. Am. Chem. Soc. 1992, 114, 3986-3988.

33. Wu, J.; Lebrilla, C. B. J. Am. Chem. Soc. 1993, 115, 3270-3275.

34. Zhang, K.; Zimmerman, D. M.; Chung-Phillips, A.; Cassady, C. J. J. Am. Chem. Soc. 1993, 115, 10812-10822.

35. McKiernan, J. W.; Beltrame, C. E. A.; Cassady, C. J. I. Am. Soc. Mass Spectrom. 1994, 5, 718-723.

36. Büker, H-H.; Grützmacher, H-F. Int. J. Mass Spectront. Ion Processes 1991, 109, 95-104.

37. Lias, S. G.; Liebman, J. F.; Levin, R. D. I. Phys. Chem. Ref. Data 1984, 13, 695-808.

38. Wu, Z.; Fenselau, C. Rapid Commun. Mass Spectrom. 1992, 6 , 403-405.

39. Carr, S. R.; Cassady, C. J. J. Am. Soc. Mass Spectrom. 1996, 7, $1203-1210$. 